\title{
Political ecology of security: tackling the illegal wildlife trade
}

\author{
Rosaleen V. Duffy ${ }^{1}$ \\ Dan Brockington \\ University of Sheffield, UK
}

\begin{abstract}
This article sets out a political ecology approach to thinking about security. It draws together conceptual debates from IR, green criminology and political ecology in order to develop new ways of thinking about and analyzing the political ecologies of security. To date political ecologists have focused on conflicts and struggles, but have not fully engaged with thinking about security. In this article we examine the ways that responses to the illegal wildlife trade have encouraged and supported greater integration between conservation and security. We use the example of the deployment of private military companies for anti poaching training and operations to tease out the key features of a political ecology approach to security; this focuses on excavating the relations between capital, nature and security, being attentive to the dynamics of race and gender, and taking an ethically engaged positionality to highlight the voices of marginalized communities. In so doing, the purpose of this article is to act as a starting point for developing a much clearer and stronger conceptual basis for political ecologists to engage with questions of security.
\end{abstract}

Key Words: Wildlife crime, illegal wildlife trade; poaching; security; anti-poaching, private military companies, capital, gender, race, class

\section{Resume}

Cet article présente une approche " political ecology » pour penser la sécurité. Il rassemble les débats conceptuels des relations internationales, de la criminologie verte et de la " political ecology " afin de développer de nouvelles façons de penser et d'analyser les écologies politiques de la sécurité. Jusqu'à présent, les écologistes politiques se sont concentrés sur les conflits et les luttes, mais ne se sont pas pleinement engagés dans la réflexion sur la sécurité. Dans cet article, nous examinons les façons dont les réponses au commerce illégal de la faune sauvage ont encouragé et soutenu une plus grande intégration entre la conservation et la sécurité. Nous utilisons l'exemple du déploiement de sociétés militaires privées pour la formation et les opérations de lutte contre le braconnage, afin de dégager les caractéristiques clés d'une approche de la sécurité basée sur la " political ecology »; celle-ci se concentre sur l'exploration des relations entre le capital, la nature et la sécurité, en étant attentive aux dynamiques de la race et du genre, et en adoptant une position éthiquement engagée pour mettre en lumière les voix des communautés marginalisées. Ce faisant, nous offrons un point de départ pour le développement d'une base conceptuelle plus claire et plus solide permettant aux écologistes politiques de s'engager dans les questions de sécurité.

Mots Clés: Criminalité liée aux espèces sauvages; commerce illégal d'espèces sauvages; braconnage; sécurité; lutte contre le braconnage; sociétés militaires privées; capital; sexe; race; classe

\footnotetext{
${ }^{1}$ Prof. Rosaleen Duffy, Department of Politics and IR, University of Sheffield, UK. Email: r.v.duffy "at" sheffield.ac.uk. Prof. Dan Brockington, Director, Sheffield Institute for International Development, University of Sheffield, UK. Email: d.brockington "at" sheffield.ac.uk. Acknowledgements: Thank you to two referees for their generous feedback on previous drafts; we also thank the BIOSEC Project research team, the Political Ecology Reading Group, Dr Jonna Nymann, Prof. Jan Selby, Dr. Lisa Stampnitzky and Dr. Jo Tidy at the University of Sheffield, and Dr. Rita Floyd, University of Birmingham, for discussing the paper at an earlier stage. We are extremely grateful to the European Research Council Advanced Investigator Award, number 694995, which funded research for this paper by Prof. Rosaleen Duffy.
} 


\section{Resumen}

Este artículo expone un enfoque de ecología política para pensar en la seguridad. En él se reúnen los debates conceptuales de las relaciones internacionales, la criminología verde y la ecología política para desarrollar nuevas formas de pensar y analizar las ecologías políticas de la seguridad. Los ecologistas políticos se han centrado en los conflictos y las luchas, pero no se han dedicado plenamente a pensar en la seguridad. En este artículo examinamos el modo en que las respuestas al comercio ilegal de especies silvestres han fomentado y apoyado una mayor integración entre la conservación y la seguridad. Utilizamos el ejemplo del despliegue de empresas militares privadas para la formación y las operaciones contra la caza furtiva, para desarrollar un enfoque de ecología política de la seguridad. Éste se centra en las relaciones entre el capital, la naturaleza y la seguridad, prestando atención a las dinámicas de raza y género, y adoptando una postura éticamente comprometida para destacar las voces de las comunidades marginadas. Con ello, el propósito de este artículo es servir de punto de partida para desarrollar una base conceptual mucho más clara y sólida para que los ecologistas políticos se comprometan con las cuestiones de seguridad.

Palabras clave: Delitos contra la fauna y la flora silvestres; comercio ilegal de fauna y flora silvestres; caza furtiva; seguridad; lucha contra la caza furtiva; empresas militares privadas; capital; género; raza; clase

\section{Introduction}

This article develops the idea of a political ecology of security to understand the implications of the increasing integration of biodiversity conservation with the security sector. It brings together conceptual debates from the fields of green criminology, international relations (hereafter IR) and political ecology to build a fresh approach. It does so via an analysis of how conservation NGOs, private firms, government agencies and other organizations are combining in new ways to respond to the illegal wildlife trade.

The articulation of biodiversity losses as an emergency has become a central feature of wildlife conservation. This is at its starkest in responses to the illegal wildlife trade, which is often cast as a security threat because of the involvement of criminal networks and its alleged role in generating finance for armed groups. The resulting emergency narratives are used to justify rapid, exceptional measures which focus on militarization, law enforcement, surveillance and intelligence gathering. Such approaches have become the first choice, rather than the option of last resort, and can crowd out alternative responses anchored in sustainable livelihoods and demand-reduction (Duffy and Massé, 2021).

The illegal wildlife trade has risen to international prominence since the rise in poaching of elephants and rhinos from 2008, and has been the center of intense international attention following the identification of the wildlife trade as the probable source of COVID-19. This attention, and sense of emergency, have galvanized calls for urgent action to tackle the illegal wildlife trade, indicating an important shift in the global politics of biodiversity conservation - a shift that fosters, supports and deepens its integration with security.

We examine these shifts by developing a political ecology of security framework. This builds on debates from IR (especially securitization theory, interventionism and environmental security), green criminology and political ecology. We combine their strengths, and bridge their gaps, to provide a fresh approach. This is important because the turn towards security has become a driving force which is rearranging conservation practices in line with broader security practices.

First, we set out the three key features of a political ecology of security. Second, we outline how the illegal wildlife trade is presented as a security problem. Third, we place these discussions in the context of existing theoretical debates. Finally, we provide an illustrative example in which we use political ecology of security to examine the growing use of private sector security companies in conservation.

\section{Political ecology of security}

In this section we set out the three elements of political ecology of security. This is necessary because when the illegal wildlife trade is defined as a security issue, it is more than just an exercise in framing, or a normal response to perceived threats. It prompts 'enforcement first' approaches by conservation NGOs, 
governments, donors and international organizations (Duffy and Massé, 2021). We need this fresh approach as a first step towards understanding the implications for conservation practice.

The political ecology of security has three intertwined aspects, which shape and co-produce each other:

1. A political ecology of security investigates the intersections between capitalism, security and nature, in order to understand how nature is being reconfigured in service of the global security industry. The current phase of conservation is more than just a return to an old model of enforcing protected areas. It is deeper and wider than that. The integration of conservation and security has brought in new actors to conservation in pursuit of new markets. When conservation and security are merged, urgent action for conservation takes on a different form, allowing security operations to be modified for conservation purposes, and vice versa.

2. A political ecology of security explores how intersectionality shapes the integration of security and conservation. The growing engagements between private companies, wildlife conservation, NGOs, surveillance and intelligence agencies, international institutions, militaries, national governments and local communities also need to be examined in ways that are attendant to, and reveal the dynamics of, different identities. These engagements reveal dynamics of race, gender, class and sexuality, and how they are intertwined with capital and security.

3. It retains political ecology's ethically engaged positionality. It is fundamentally concerned with highlighting social and environmental injustices, perpetrated against people, and wildlife. It casts light on how and why benefits and harms are unevenly distributed in the human and nonhuman worlds.

In the following section we examine how illegal wildlife trade is presented as a security problem. Second, we discuss the theoretical debates that we build on to develop our approach. Third, we use an illustrative example to indicate how it might be used in future political ecology research.

\section{The rise of wildlife crime as a security problem}

The illegal wildlife trade has been (re)defined as 'wildlife crime', and as a serious crime, which funds non-state armed groups and organized crime networks (Duffy, 2016; Massé et al. 2020). This way of thinking about illegal wildlife trade adds to conservation biology's self-identity as a 'crisis' discipline. Conservation is constituted by a sense of urgency around a core set of objectives to sustain species and ecosystems: prevent extinctions and halt habitat degradation. Soulé argues that conservation biology, as a crisis discipline, must mix art and science because "[i]n crisis disciplines one must act before knowing all the facts . . . they require intuition as well as information" (1985: 727). ${ }^{2}$ More broadly, scientists are asked to provide advice to diverse stakeholders, based on incomplete and uncertain information.

These dilemmas mirror some of the challenges in security thinking, especially the need to act in uncertain situations without complete information. With the end of the Cold War, so-called new security threats proliferated, including emerging diseases, biochemical weapons, population displacements, climate change and water shortages. The post-Cold War period also saw the rise in 'human security' approaches that moved beyond the narrower 'state security' remit (McDonald, Barnett and O'Brien, 2010; Dalby, 2009; Nyman, 2016). There has been a marked rise in international interventions, faith in ideas of pre-emption and conflict prevention, use of force, and increasing acceptance of private sector operators in delivering security. These shifts have also played out in strategies to tackle the illegal wildlife trade, especially the contracting of private sector security companies to provide anti-poaching and training, as discussed later in this article. Until now these ways of thinking about security have been confined to threats to the human world. Now they

2 Also see the Crisis Conservation Project, led by Prof. Bram Büscher, Wageningen University, https://crisisconservation.org (Accessed 5 October 2021). 
extend to the urgent need to save wildlife, to secure ecosystems and biodiversity as well as local and global stability. As Duffy and Massé (2021) argue, viewing illegal wildlife trade through the lens of crime and security leads on to an 'enforcement first' approach (also see Lunstrum et al., 2021). The argument that poaching and trafficking are matters of crime and security rather than of inequality, development, livelihoods or consumer demand, is then deployed to justify the use of emergency responses, including often extra-legal and violent measures.

Gore (2017) argues that the rise in interest from global policy makers in tackling illegal wildlife trade is because there is growing agreement that wildlife losses have produced a convergence of threats to ecosystems, geopolitical stability, national security, human health, well-being, and future generations (also see Massé, et al., 2020; Moreto, 2018; Van Uhm and Moreto, 2018). This has far-reaching implications, because the articulation of conservation as a security concern changes the nature of conservation; security and conservation have, or have had, different objectives, and even divergent methods for achieving them. Furthermore, the scope and scale of interventions for security are more far-reaching, extensive and intensive, than those that conservation has previously been able to elicit.

A wide range of organizations draw the link between organized crime and wildlife trafficking including the UN Economic and Social Council (ECOSOC), INTERPOL, UNEP and the United Nations Security Council (Elliott, 2016: 27-28; Wasser et al., 2015). The EUROPOL Serious and Organized Crime Threat Assessment (SOCTA) ${ }^{3}$ highlights the role of organized crime groups in wildlife trafficking. ${ }^{4}$ The United Nations Convention Against Transnational Organized Crime (UNTOC) and the United Nations Office on Drugs and Crime (UNODC) include wildlife and timber trafficking in their remit, and provide a framework for approaching transnational organized crime. From 2012 all activities to address wildlife and forest crime were brought under the first UNODC Global Program on Combating Wildlife and Forest Crime, managed by the UNODC headquarters in Vienna. ${ }^{5}$ Further, in 2015 the United Nations issued a resolution identifying wildlife crime as akin to drug and people trafficking, and urged member states to increase efforts to tackle it. ${ }^{6}$

The reconfiguration of wildlife crime as a form of serious and organized crime is echoed by a range of international institutions and conservation NGOs including CITES, INTERPOL, the EU, the World Wide Fund for Nature, United for Wildlife, Conservation International, The Nature Conservancy, and many others. For example, WWF-International states "[i]ncreasingly involving large-scale, transnational organized crime, the current unprecedented spike in illegal wildlife trade poses a growing threat not only to wildlife but also to security, rule of law, sustainable development, and the well being of local communities."7

The argument that the illegal wildlife trade generates funds for armed groups and terrorist networks is central to debates in policy networks, especially in US Government circles. This translates into greater attention, support and funding for tackling the illegal wildlife trade because it is a threat to US interests. In 2013 President Barack Obama issued Executive Order 13648 on Combating Wildlife Trafficking and in 2016 passed the END Wildlife Trafficking Ac. ${ }^{8}$ This commitment did not diminish during the Trump Administration, which implemented the END Wildlife Trafficking Act, and the 2016 Intelligence Authorization Act mandated the Director of National Intelligence to report on wildlife trafficking networks

${ }^{3}$ EUROPOL, Threat Assessment, Accessed 8 March, 2019 https://www.europol.europa.eu/activities-services/mainreports/serious-and-organized-crime-threat-assessment

${ }^{4}$ EUROPOL, Threat Assessment 2013.

${ }^{5}$ Broussard, "United Nations," 463.

6 United Nations, Tackling illicit trafficking in wildlife. Accessed 12 September, 2020 http://www.un.org/en/ga/search/view doc.asp?symbol=A/69/L.80

7 https:/wwf.panda.org/discover/our focus/wildlife practice/wildlife trade/wildlife crime initiative/ Accessed November 2020.

${ }^{8}$ White House (Obama Administration), Combating Wildlife Trafficking, Executive Order 13648 of July 1, 2013, Federal Register 78(129), July 5, 2013, pp. 40621-40623; Report to Congress on Major Wildlife Trafficking Countries. Eliminate, Neutralize, and Disrupt (END) Wildlife Trafficking Act of 2016 P.L. 114-231, Section 201, 22 October 2020 https://www.state.gov/2020-end-wildlife-trafficking-report/ Accessed 5 October 2021. 
and targets for disruption (Felbab-Brown, 2017: 11). In 2017, the illegal wildlife trade was specifically mentioned in Trump's Presidential Executive Order on Enforcing Federal Law with Respect to Transnational Criminal Organizations and Preventing International Trafficking. ${ }^{9}$

These concerns are visible in shifts in donor funding as well. ${ }^{10} \mathrm{~A}$ review of Global Environmental Facility (GEF) funding in 2016 found that $19 \%$ of the US $\$ 1.3$ billion committed by 24 donors between 2010 and 2016 went to law enforcement, including intelligence-led operations and transnational coordination (Wright, et al. 2016: 9). In 2018-2019 GEF was the biggest donor tackling the illegal wildlife trade. ${ }^{11}$ The World Bank analysis of donor funding for tackling illegal wildlife trade, indicated that in total it committed US\$19 million between 2010-2016 (Wright et al., 2016). Massé and Margulies (2020) analyzed 4,142 projects funded by the USFWS, and found a shift in funding towards projects concerned with security and enforcement, and away from sustainable livelihoods, development and demand reduction strategies.

These shifts towards security-oriented approaches are also supported by philanthropists. For example, Kruger National Park in South Africa received US\$25 million from the Howard G. Buffett Foundation to set up an Intensive Protection Zone for rhinos inside the park (Duffy, 2014). Philanthropy, especially wealth derived from tech-entrepreneurs also supports technological approaches to tackling the illegal wildlife trade including surveillance systems used in anti-poaching (Massé, 2018). For example, Vulcan Inc. Philanthropy, is the foundation of the Paul G. Allen family (a co-founder of Microsoft) and one of the most active funders for the tech for conservation (see also Holmes, 2012). ${ }^{12}$

The confluence of philanthropy, security and conservation opens up new markets in conservation, from which the private sector can benefit substantially. The expansion of funding coincided with the rise in private security companies offering their services to conservation as military personnel were demobilized from successive US-led interventions in the Middle East. Many of these are now active in conservation work.

\section{Developing a political ecology of security}

In order to understand how conservation and security have become more integrated, we develop a framework that draws on elements of green criminology, political ecology and IR. Current frameworks in these separate fields are not fit for our purposes for several reasons. As Dauvergne and Clapp (2016) note, global environmental politics has increasingly focused on climate change and on analyzing market-based instruments of governance, obscuring other environmental issues and alternative intellectual approaches. Dauvergne and Clapp also point out that much existing scholarship in IR does not treat the environment itself as the central focus of research. Rather it is used to illustrate debates about the nature of governance arrangements. Scholars of the broad fields of global environmental politics and political ecology would benefit from greater engagement in each other's work. There are some examples of research which bridges both political ecology and global environmental politics (on climate change by Selby et al., 2017 and on conservation by Duffy, 2016; Marijnen and Verweijen, 2016, and on conflict and the environment by Verweijen, 2020; Marijnen, De Vries and Duffy, 2020; and Le Billon and Duffy, 2018). Political geographers have engaged more fully in debates about the relationships between environment, geopolitics and security in the form of environmental geopolitics (O'Lear 2018) - an arena in which environmental narratives are used to support geopolitical arguments and realities.

Traditionally, political ecology combines insights from ecology and political economy (Blaikie and Brookfield, 1987; Robbins 2012). Joan Martinez-Alier (2003) classically defines political ecology as the study of ecological distribution conflicts. Paul Robbins (2012) identifies five major areas of political ecology:

\footnotetext{
${ }^{9}$ White House, Executive Order, https://www.whitehouse.gov/the-press-office/2017/02/09/presidential-executive-orderenforcing-federal-law-respect-transnational Accessed 19 September 2020.

${ }^{10}$ These sums are small compared to overall expenditure on conservation, estimates of which varies between US\$78 and US\$143 billion per year (Perry and Karousakis, 2020: 3; Deutz et al., 2020: 13). However, our point is not that such security concerns dominate spending, but rather that they are growing in influence.

11 Global Environment Facility, Funding to combat illegal wildlife trade, GEF, Accessed 23 November 2019, https://www.thegef.org/news/gef-increases-funding-combat-illegal-wildlife-trade

12 https://vulcan.com Accessed 5 January 2021; http://www.greatelephantcensus.com Accessed 22 October 2021.
} 
environmental conflicts, degradation and marginalization, conservation and control, environmental identity, and social movements. While its foundations lie in political economy and ecology, as political ecology has developed as a field of enquiry it has incorporated insights from other fields to build new post-structuralist and feminist political ecologies (Rocheleau, Thomas-Slayter and Wangari, 2013).

One of the core strengths of political ecology is to understand and examine socio-ecological relations. Yet to date, political ecologists have not fully explored what is meant by security, for whom and with what effects. There is some excellent research which does address questions of securitization in conservation. For example, Massé and Lunstrum's (2016) analysis of the Greater Lebombo Conservancy between Mozambique and South Africa demonstrates how securitizing discourses and practices produce new enclosures and capital accumulation. The discourses and logics of security have supported rhino protection in private reserves, allowing the entry of private sector security operators amid promises of greater profits from increased tourism (also see Massé, 2018; Büscher 2021). However, in this article we want to build on this to go one step further to develop a distinctive political ecology of security as a framework for analyzing engagements between security and conservation.

Political ecologists have developed important critiques of environmental security, especially for its neo-Malthusianism, its methods and its failure to address local level complexities that produce conflict (Peluso and Vandergeest, 2011; Le Billon and Duffy, 2018; Benjaminsen et al., 2012). Political ecologists have examined the interplay between resources, conflicts and environmental change (Peluso and Watts, 2001; Le Billon, 2012; Bocarejo and Ojeda, 2018) and highlighted the growing intersections between the environment and the military (Bigger and Neimark, 2017). They have also examined resource conflicts, although not the broader debates from peace and conflict studies (Le Billion and Duffy, 2018). Similarly, the focus on marginalized peoples has clear potential to intersect with human security approaches from security studies (McDonald, Barnett and O'Brien, 2010; Dalby, 2009) although this has not yet been realized. Political ecology can also draw more fully on debates in IR about security, which are concerned with what security means, for whom and how can it be achieved. In this regard, two strands, environmental security and securitization theory, are particularly useful.

The environmental security debate arose in the 1990s from the notion that environmental degradation was a security threat. Research using an environmental security perspective investigated the link between natural resource scarcity and abundance in producing armed conflict (Homer-Dixon, 1999). Since then, further work has explored the role of climate change, water scarcity and mineral extraction (but not biodiversity conservation) in conflict (see O'Lear, 2018; Selby, Dahi, Fröhlich and Hulme, 2017). Environmental security's weakness is its deterministic approach to understanding how environmental degradation causes violent conflict and its use of large $\mathrm{N}$ databases, which rely heavily on annual inter-state conflict data rather than in-depth case studies (Le Billon and Duffy 2018; Benjaminsen et al., 2012; Peluso and Watts, 2011). In contrast a strength of political ecology is research on how conservation can produce conflict through the injustice it inflicts, especially among marginalized communities (Duffy 2002; Jacoby, 2003). Environmental protection does not just conserve, it extends state power; and biodiversity conservation can be central in attempts to quell, control, or displace unruly groups (Ybarra, 2012; Peluso and Vandergeest, 2011). However, while political ecologists have been central to critiques of environmental security, they need to engage much more fully with debating what security means, and for whom.

Securitization theory in IR provides further insights, which political ecologists could engage with more fully. There are some political ecology studies which use the term securitization (Massé and Lunstrum, 2016; Witter, 2021), but in this article, we argue that it is important to understand and acknowledge its roots in IR; further, it is vital that we address its limitations for thinking about the current security phase of conservation, rather than adopting the term as a broad badge. We expressly do not use the term securitization in this article as a means to describe conservation issues. Securitization debates explore how particular issues become discursively constructed as security challenges. Security discourses and framings play out not just in speech acts, but materially, and violently, on the ground for people and wildlife. The Copenhagen School argues that (generally) elite actors construct security issues by discursively framing them as such (referred to as speech acts). This then instigates new emergency measures beyond the realm of normal politics, and 
should be seen as a failure of normal politics (Buzan et al., 1998; Booth, 1991; Floyd, 2011; Dalby, 2009; Nyman, 2016).

There are substantial criticisms of securitization theory. For example, it is primarily concerned with how social practices become securitized, which presupposes distinct phases before and after securitization (with some exceptions, see Oels 2012 on climatization of security). This makes it difficult to understand securitization as an on-going process. In the fast-paced efforts to tackle the illegal wildlife trade, framings and practices are involved in a continuous two-way interaction between conservation and security. Further, there have been recent criticisms that the roots of securitization are both racist and gendered (Howell and Richter-Montpetit, 2020). Therefore, while elements of securitization theory are useful, on its own it does not adequately capture the dynamics of the integration of security and conservation.

A political ecology of security also builds on elements of the growing field of green criminology, which can be understood as the study of crime, harm, and injustice related to the environment. Green criminologists are interested in exploring and revealing the power relations that shape understandings of what constitutes a crime, which is compatible with a political ecology approach. Wyatt (2013) argues that the illegal wildlife trade is a growing area of interest for green criminologists. Portrayals of the illegal wildlife trade as a harm, or a crime against humanity and the environment, are often deployed by conservationists to promote urgent, and even forceful, action. Green criminologists have been at the forefront of thinking through how wildlife crime can be regarded as a harm without supporting the use of forceful responses (see Wyatt, 2013; Gore, 2017; Spapens, White, Van Uhm \& Huisman, 2018). However, our framework further develops this understanding of the distribution of harms by analyzing the role of capital in producing environmental crime (as we discuss below).

Environmental security, securitization and green criminology are all useful as building blocks for a political ecology of security, but they have limitations. They cannot offer a sufficient explanatory framework for the ways that security and biodiversity conservation have become more integrated. The neo-Malthusian, environmentally-determined arguments of environmental security do not capture the nature of an anthropogenic crisis. The Copenhagen School's focus on discourse cannot explain poaching patterns, the violent practices in some forms of anti-poaching or the intersections of race, class gender and sexuality. These are more than 'speech acts.' They are imprinted on the landscape, on the bodies of animals and on people. Green criminology is a useful approach but needs to engage more fully with the global politics of how and why harms are distributed in ways that intersect with race, gender, sexuality and class. Political ecology does engage well with the struggles of marginalized peoples, and with intersectional dynamics, but has focused on specific ecological distribution conflicts, rather than how these relate to questions of global security. Therefore, it is important to develop political ecology further such that it engages with questions of global security much more fully. In this article we suggest a political ecology of security as a first step in doing so. This is important for three reasons:

First it reveals how conservation and security are mutually shaping each other's knowledge and practices. The convergence of conservation and security is restructuring human relations with the environment, and relations between wildlife (encompassing plants and animals) and their environments.

Second, the integration of conservation and security changes present conservation practices, and shape conservation in the future. It defines what conservation can, and, more importantly, cannot be. The new security-oriented approach opens new partnerships with private military companies, weapons manufacturers, intelligence services and tech companies. This can cut out or alienate other potential collaborators, including local communities, environmental activists and grassroots development NGOs. It can mitigate against conservation solutions which are not anchored in security, but rather in addressing inequality, sustainable livelihoods and demand reduction instead.

Third, taking a security-oriented approach to the illegal wildlife trade, ultimately, will not solve the problem of species losses. A security-oriented approach may still produce positive outcomes in some locations in the short term (Duffy et al., 2019). However, these achievements are counted using narrowly defined measures of success: arrests, seizures of illicit goods, or reductions in rates of poaching. Ultimately, any claims to success must encompass the ripple effects of such strategies in local and international arenas. In 
the next section we use a brief illustrative example to indicate how this framework can be used to analyze responses to the illegal wildlife trade.

\section{The political ecology of security and illegal wildlife trade}

The expansion of private sector military and security operators in conservation has accelerated as a result of a convergence of factors: the availability of demobilized military personnel from interventions in the Middle East, a normalization of the use of private military companies, and the broader privatization of security (Pattison, 2014). A sense of urgency in the conservation sector has also brought about the 'security turn.' A political ecology of security allows us to sketch out how it can be used, and to identify areas for future research. Our research was conducted as part of a larger project, funded by the European Research Council, which took a qualitative and iterative approach, drawing on official documents, knowledge exchange workshops, participant observation in high-level meetings and semi structured interviews with key informants between 2014 and 2020. The 43 interviewees were drawn from conservation NGOs (eight), military trainers working in conservation (five), international donors (thirteen) and relevant national government agencies in the US and UK (seven) as key actors in funding and campaigning. Interviews were fully anonymized and participants were given the opportunity to review and amend the full transcript of the interview.

\section{Capital, nature and security}

The proliferation of private sector conservation security companies is one of the most prominent aspects of the intermeshing of the security industry with the conservation sector. Despite the scandals surrounding the use of private intelligence and security operations the past (such as the relationship between WWF-International and KAS Enterprises in the 1990s) the practice is expanding (Rademeyer, 2012; Massé, Lunstrum and Holterman, 2018). Conservation mirrors wider developments in the security sector more broadly, which has seen the expansion of Private Military Companies offering a range of services from bodyguards to humanitarian assistance to protection of oil platforms (Pattison, 2014). High-profile examples include Erik Prince's Blackwater (later called Academi), Veterans Empowered to Protect African Wildlife (VETPAW), Maisha Consulting, International Anti Poaching Foundation (IAPF) and Chengeta Wildlife. They are staffed by ex-military personnel, often with experience of international interventions in Afghanistan and Iraq (Humphreys and Smith, 2014: 81).

The privatization of security has become more common and normalized following US-led interventions in Iraq and Afghanistan. This wider dynamic of the privatization of security has also shaped conservation practice as security companies search for new markets for their skills. This search matched an apparent need, as conservationists expressed concerns that wildlife crime, poaching and insecurity constituted rising threats to some iconic species.

It is useful to reflect on what motivates people to move into conservation following a military career. Lombard and Tubiana (2020) suggest that the shift from the military into conservation can be seen as part of the wider career path of some individuals. It is clear that money is not the only motivation. One private contractor engaged in training US military veterans in conservation pointed out their commitments to wildlife, given that they could earn far more in private military sector:

On average, our veterans, the guys and girls that go out on the ground and do this work, they can go and be working for Blackwater or Triple Canopy....They could go and be working for them in Afghanistan and making $\$ 500$ or $\$ 600$ a day, not counting per diem. A lot of our guys and girls on the ground, they volunteer their time. They're not even getting paid. ${ }^{13}$

\footnotetext{
${ }^{13}$ Interview with 202004 _13 WP1.20b.
} 
For many of the ex-military who join, it is because of a genuine commitment to wildlife and because they feel their skills and 'can do' attitude can be of use. One war veteran who now works in conservation, explained how his initial motivation came about. He had watched a documentary on CNN showing the (now infamous) footage of an elephant with its trunk severed, and a rhino in South Africa, which was still alive and bleeding profusely following the removal of its horn by poachers. He described how "all of my emotions from war that I had stuck into a jar, screwed on as tight as I could, super-glued it shut, that rhino, that elephant, and that whole documentary, unscrewed that jar." ${ }^{14}$ However, he recognized that feeling such an intense response, a need to do something to save these animals, was not necessarily the best motivation, and had led to some mistakes and challenges for his organization when he first set it up. He emphasized that several years on, his organization does not accept trainees that describe their motivations in this way because they still need to address the deep emotional effects of their experiences of warfare.

Furthermore, recruits can be attracted to conservation because the work can have positive impacts on mental health. VETPAW explicitly states that its work can help veterans come to terms with Post Traumatic Stress Disorder (PTSD), following combat experience. The Director of one of these private military organizations, a US veteran who served in Iraq, was proud that their conservation work could have beneficial mental health effects for their staff; he remarked "it's really beautiful, they are saving the animals, but the animals are also saving them." 15 The perceived healing and regenerative effects of being in an 'African' context were also cited as a positive impact on mental health for those who made the shift to conservation, as one trainer commented,

We don't bring veterans out that are just shattered by PTSD. PTSD is something you always live with, you manage it, you cope. We have veterans that come out and they're able to decompartmentalize and make sense of everything that they've gone through because, you're in Africa, it's healing. ${ }^{16}$

This is important because, as White suggests in his study of veterans working in private sector security, PTSD presents a challenge for the private sector, around whether the private companies take responsibility for caring for and paying for treatment for staff who display PTSD while they are under contract, and afterwards (White, 2019).

The engagement of private contractors goes beyond simply using them for specific operations or skills, or providing them with employment opportunities and a chance to address PTSD. The securityoriented approach also means that ranger training can be transformed away from the usual roles of park rangers and towards a focus on military-style training and counter-insurgency tactics (Lunstrum, 2014) which is not always welcomed by rangers themselves (Annecke and Masubelele, 2016). Such a shift inevitably changes the nature of potential recruits, attracting applicants who might be more amendable to military style approaches. One private contractor made it clear that there was a genuine interest amongst rangers in learning more about the techniques of US warfare, he commented that,

I found that a lot of park rangers, and a lot of Africans in general, were very up to date and up to speed with the American wars. They were blown away that a US veteran was coming over to share some of these skills with them. ${ }^{17}$

We need more research on why rangers desire military-style training. Moreto and Charlton (2021) point out, rangers in Uganda receive paramilitary training, and consider traditional law enforcement methods as

\footnotetext{
${ }^{14}$ Interview with 2020_04_13 WP 1.20a

${ }^{15}$ Interview with 2020_04_13 WP $1.20 \mathrm{a}$

${ }^{16}$ Interview with 2020_04_13 WP 1.20a.

${ }^{17}$ Interview with 2020_04_13 WP 1.20 b.
} 
important, but not sufficient, to tackle illegal activity in protected areas. Instead, they expressed a desire for more training on community relations and policing techniques. Studies of militarization in conservation rarely focus on the rangers themselves. There is considerable variation in ranger roles, practices and training across the world, and so a political ecology of security could assist in teasing out these nuances around the perspectives and motivations of rangers themselves.

The political economy of conservation's integration with security encourages particular ways of thinking about conservation, which can be more oriented towards their own worldviews that may not match those of local communities and national governments (Massé, Lunstrum and Holterman, 2018; Roe et al., 2015). This includes categorizing types of people or groups as enemies as well as areas or 'things' to be defended. Further, as Day (2020) points out, the precise form of militarization of conservation differs across contexts and is shaped by wider state-society relations. A political ecology of security approach, then, investigates the intersections between capitalism, security and nature, in order to understand how nature is being reconfigured in service of the global security industry.

\section{Intersectionality: race, class, sexuality and gender}

There is an under-acknowledged politics of race, class, sexuality and gender in many of these new conservation initiatives used to tackle illegal wildlife trade by using private sector security contractors. A political ecology of security allows us to highlight and examine these. There is an emerging literature which aims to centre race, class, gender and sexuality in conservation. For example, Burnett and Milani (2017) demonstrate how the gendered construction of racial subjects is used to justify the killings of rhino poachers in South Africa. Thakholi (2021), by contrast, focuses on conservation labor geographies to examine how the workforce cannot be divorced from the gendered and racialized production of space in South Africa. Her research demonstrates how the increasing demand for anti-poaching units produce new forms of employment for young black men. These same men then face mistrust in their home communities, and experience trauma from their involvement in militarized enforcement.

Here we provide a brief example of the intersections of race, sexuality and gender with conservation, but much more work can be done using a political ecology of security framework. The International Anti Poaching Foundation (IAPF), was set up by Damien Mander in 2009. Originally trained in the Australian Navy and the Army Special Forces, he went on to work in Iraq with private military companies. When he set up IAPF he stated that he would use it to apply the lessons he learned in Iraq to anti-poaching (primarily in Zimbabwe and Mozambique). ${ }^{18}$ Following his initial work, Mander set up a women only anti-poaching unit called Akashinga in the Zambezi Valley in Zimbabwe. It has received a great deal of media attention, including an eponymous National Geographic documentary. ${ }^{19}$ All women anti-poaching units, such as the Black Mambas in South Africa ${ }^{20}$ and Akashinga in Zimbabwe, are often presented as a means of empowering women. Akashinga for example, is presented as a win-win for conservation and women's empowerment because recruits have experienced domestic violence, and now have an opportunity to earn an income and gain ranger training. ${ }^{21}$

These initiatives offer stories which capture the attention and imagination of external audiences. Further there is politics of race which is generally not discussed, but which is present in the visual coverage of Akashinga: that of white male military trainers imparting knowledge to African 'recipients.' This neatly intersects with a long history of imagery of a white savior bringing aid and support to needy Africans. As Thakholi (2021) points out, white conservation labor is often celebrated, while black conservation labor is not valorized in the same ways (also see Burnett and Milani, 2017). A political ecology of security

\footnotetext{
${ }^{18}$ IAPF, "Homepage," Accessed 27 March 2020 http://www.iapf.org

${ }^{19}$ Akashinga: the Brave Ones https://films.nationalgeographic.com/akashinga Accessed 28 May 2020.

${ }^{20} \mathrm{https}: / / w w w . b l a c k m a m b a s . o r g$ Accessed 27 May 2020.

${ }^{21}$ The Guardian (UK), Africa's new elite force: women gunning for poachers and fighting for a better life, Accessed 19 December 2020 https:/www.theguardian.com/environment/2017/dec/17/poaching-wildlife-africa-conservation-womenbarbee-zimbabwe-elephant-rhino
} 
framework helps us tease out these important connections with wider dynamics of intersectionality, and highlights the need for much more research on the views of workers in the conservation sector, including rangers, war veterans and military trainers working in conservation.

\section{Ethical engagement: human rights, militarization and conservation}

The expansion of private military companies operating in conservation, especially in Sub-Saharan Africa has generated concerns about the variation in practices, professionalism and in oversight. Despite the proliferation of these organizations there is no common code of practice or set of guidelines governing them. The variability in the quality of groups operating in conservation mean that some have sought to distance themselves from other companies or individuals in order to protect their reputations. One representative of a conservation organization which trains and deploys veterans, expressed their concerns that there were now so many of these kinds of NGOs being established by US war veterans, with little regulation and oversight from either the US Government or the Governments of the countries they operate in. The variability in quality of work and types of practices, they said, were giving all such organizations "a bad name." In this organization recruits are carefully vetted and undergo a rigorous and intensive three-week mental and physical training program. Only a small proportion of applicants are ever approved to work on the ground in a range of African countries, and that when they do so they are deployed with the full knowledge and approval of the relevant government. ${ }^{22}$ This has raised concerns amongst private sector militaries that their roles may be more generally misunderstood, as one private contractor commented, "There was a misconception, is a misconception, that organizations like ours are there as mercenaries."23 Another remarked that:

We don't want to be painted with that same brushstroke because, as you can see, it happened. These other organizations can taint a reputation that other people have worked so hard to build.... You screw up one time and we're all screwed. ${ }^{24}$

These concerns need to be seen against a context of well-documented human rights abuses as a result of conservation initiatives and criticism of militarization, especially in the field of anti-poaching. Political ecologists have been at the forefront of the debate on the negative impacts of militarization for marginalized communities (see Lunstrum 2014; Marijnen and Verweijen, 2016; Verweijen, 2020; Marijnen, De Vries and Duffy, 2020; Duffy et al., 2019; Büscher and Ramutsindela, 2016; Massé, 2018; Dutta, 2020; Witter, 2021; Weldemichel, 2020). Furthermore, a political ecology of security framing could develop much needed research on the motivations and perspectives of people who engage in illegal hunting. Witter's (2021) excellent study of how poaching can constitute an act of resistance and defiance is a rare example of research that focuses on the perspectives of the communities that experience militarized conservation.

NGOs campaigning on indigenous rights and on human rights have raised important criticisms of militarization. Since 2015 Survival International has run a campaign entitled 'Stop the Con' about the abuses by conservation authorities in India, Cameroon and Central African Republic. ${ }^{25}$ Rainforest Foundation UK have also produced several reports on abuses of forest peoples in the Congo Basin (Pyhälä, Osuna- Orozco and Counsell, 2016). In March 2019 Buzzfeed news published a high profile article based on a year long investigation into human rights abuses by rangers employed or trained by WWF in Chitwan National Park (Nepal), Kaziranga National Park (India) and across several locations in Africa. ${ }^{26}$ In drawing attention to these abuses in conservation our approach retains and builds on political ecology's ethically engaged

\footnotetext{
${ }^{22}$ Interview with 2020_04_13 WP1.20b

${ }^{23}$ Interview with 2020_04_13 WP $1.20 \mathrm{~b}$

${ }^{24}$ Interview with 2020_04_13 WP 1.20a

25 https://www.survivalinternational.org/stopthecon Accessed 03 July 2020)

${ }^{26} \mathrm{https}$ ://www.buzzfeednews.com/article/tomwarren/wwf-world-wide-fund-nature-parks-torture-death Accessed 7 March 2019.
} 
positionality; it is important to cast light on how and why benefits and harms are unevenly distributed, and how conservation can be implicated in producing injustices on the ground.

\section{Conclusion}

A political ecology of security builds on debates from IR, political ecology and green criminology in order to interrogate the ways that global security is articulated via environmental change, often in problematic and concerning ways. By bringing three existing fields together in political ecology of security, we build on their strengths and move them forward. For example IR can benefit from more engagement with the locally grounded case study approach of political ecology, while political ecology can benefit from developing more of the global context for local level dynamics, and green criminology can draw more fully on political ecology to examine the power inequalities in producing harms.

A political ecology of security has three key features. First it is concerned with developing an understanding of the relations between capital, nature and security understand how the environment is rendered amenable to the logics of security and the global industry it sustains. Second, it recognizes the importance of the dynamics of intersectionality including race, sexuality, class and gender shape the ways that a range of actors co-produce the integration of conservation and security. Third, in line with key traditions of political ecology, this approach requires an ethically engaged positionality, concerned to highlight injustices for people and wildlife.

The framework needs to be developed through future work, especially on the relationships between donors, states and conservation NGOs, on the perspectives of poachers themselves, and on the intersections of race, class, gender and sexuality in the development of militarized conservation. It is needed because the integration of conservation and security is fundamentally restructuring relationships between the human and non-human worlds. It is changing the interactions between people, between people and the environment, and between animals and the ecosystems they inhabit. Further, this approach can be more widely applicable to a range of environmental challenges that are being articulated as security threats, including fisheries, freshwater, climate, forests, mineral extraction and pollution.

The convergence of the security industry with the conservation sector allows militaries, private sector security companies, intelligence, and risk analysts to benefit financially, and in reputational terms, as concerned conservationists. For conservationists, it brings important new streams of funding, a great deal of attention from the public, and policy commitments from some of the world's most powerful actors. Applying a political ecology of security framework in order to understand these challenges allows us to uncover the power dynamics around the ways that security thinking and practices are shaping, and being shaped, by global environmental change.

\section{References}

Annecke, W. \& Masubelele, M. (2016). A review of the impact of militarization: The case of rhino poaching in Kruger National Park, South Africa. Conservation and Society, 14(3): 195-204. http://doi.org/ $\underline{10.4103 / 0972-4923.191158}$

Benjaminsen, T. A., Alinon, K., Buhaug, H. \& Buseth, J. T. (2012). Does climate change drive land-use conflicts in the Sahel? Journal of Peace Research, 49: 97-111. https://doi.org/10.1177\%2F0022343311427343

Bigger, P. \& Neimark, B. D. (2017). Weaponizing Nature: The geopolitical ecology of the US Navy's biofuel program. Political Geography, 60: 13-22. https://doi.org/10.1016/j.polgeo.2017.03.007

Blaikie, P. M. \& Brookfield, H. C. (1987). Land degradation and society. Routledge.

Bocarejo, D., \& Ojeda, D. (2016). Violence and conservation: Beyond unintended consequences and unfortunate coincidences. Geoforum, 69: 176-183. https://doi.org/10.1016/j.geoforum.2015.11.001

Booth, K. (1991). Security and emancipation. Review of International Studies, 17: 313-326. 
Brockington, D. (2002). Fortress conservation: The preservation of the Mkomazi Game Reserve, Tanzania. James Currey.

Burnett, S. \& Milani, T. (2017). Fatal masculinities: A queer look at green violence. ACME: An International Journal for Critical Geographies, 16(3): 548-575.

Büscher, B. (2021). Between overstocking and extinction: conservation and the intensification of uneven wildlife geographies in Africa. Journal of Political Ecology, 28(1). https://doi.org/10.2458/jpe.2956

Büscher, B. \& Fletcher, R. (2018). Under pressure: Conceptualizing political ecologies of green wars Conservation and Society, 16(2): 105-113. http://do.org/10.4103/cs.cs 18 _ 1

Büscher, B., \& Ramutsindela, M. (2016). Green violence: Rhino poaching and the war to save Southern Africa's Peace Parks. African Affairs, 115: 1-22. https://doi.org/10.1093/afraf/adv058

Buzan, B., Waever, O. \& de Wilde, J. (1998). Security: A new framework for analysis. Lynne Rienner.

Corson, C. (2016). Corridors of power: The politics of environmental aid to Madagascar. Yale University Press.

Dalby S. (2009). Security and environmental change. Polity.

Dauvergne, P. \& Clapp, J. (2016). Researching global environmental politics in the $21^{\text {st }}$ Century. Global Environmental Politics, 16(1): 1-12. https://doi.org/10.1162/GLEP_e_00333

Day, C. (2020). Sister Forces: Park rangers and regime security in African states. Civil Wars, 22(2-3): 353378. https://doi.org/10.1080/13698249.2020.1755162

Duffy, R. V. (2014). Waging a war to save biodiversity: The rise of militarized conservation. International Affairs 90(4): 819-834.

Duffy, R. V. (2016). War by conservation. Geoforum 69: 238-248.

Duffy, R. V. \& Massé, F. (2021). The integration of conservation and security: Political ecologies of violence and the illegal wildlife trade. In Sowers, J., VanDeveer, S. D. \& Weinthal, D. (eds.). The Oxford handbook of comparative environmental politics. Oxford University Press.

Duffy, R. V., Massé, F., Smidt, E., Marijnen, E., Büscher, B., Verweijen, J., Ramutsindela, M., Simlai, T., Joanny, L. \& Lunstrum, E. (2019). Why we must question the militarization of conservation. Biological Conservation 232: 66-73. https://doi.org/10.1016/j.biocon.2019.01.013

Elliott, L. (2016). Criminal networks and illicit chains of custody in transnational environmental crime. In Elliott, L. \& Schaedla, W.H. (eds.). Handbook of transnational environmental crime. (pp. 24-44). Edward Elgar.

Felbab-Brown, V. (2017). The extinction market: Wildlife trafficking and how to counter it. Oxford University Press.

Floyd, R. \& Matthew, R. (2013). Environmental security: Approaches and issues. Routledge.

Floyd, R. (2011). Can securitization theory be used in normative analysis? Towards a just securitization theory. Security Dialogue, 42 (4-5): 427-439. https://doi.org/10.1177\%2F0967010611418712

Gore, M. (2017). Global risks, conservation and criminology. In Gore, M. (ed.). Conservation criminology. (pp. 1-23). Wiley-Blackwell.

Holmes, G. (2012). Biodiversity for billionaires: Capitalism, conservation and the role of philanthropy in saving/selling nature. Development and Change, 43: 185-203. https://doi.org/10.1111/j.14677660.2011.01749.x

Homer-Dixon, T. (1999). Environment, scarcity, and violence. Princeton University Press.

Howell, A. \& Richter-Montpetit, M. (2020). Is securitization theory racist? Civilizationism, methodological whiteness, and antiblack thought in the Copenhagen School, Security Dialogue, 51(1): 3-22. https://doi.org/10.1177\%2F0967010619862921

Jacoby, K. (2003). Crimes against nature squatters, poachers, thieves and the hidden history of American Conservation. University of California Press.

Le Billon, P. (2012). Wars of Plunder: Conflicts, profits and the politics of resources. Columbia University Press. 
Le Billon, P. \& Duffy, R. V. (2018). Conflict ecologies: Connecting political ecology and peace and conflict studies. Journal of Political Ecology, 25(1): 239-260. https://doi.org/10.2458/v25i1.22704

Lunstrum, E. (2014). Green militarization: Anti-poaching efforts and the spatial contours of Kruger National Park. Annals of the Association of American Geographers, 104: 816-832. https://doi.org/10.1080/00045608.2014.912545

Lunstrum, E., Givá, N., Massé, F., Mate, F., \& Jose, P. L. (2021). The rhino horn trade and radical inequality as environmental conflict. The Journal of Peasant Studies, 1-21. https://doi.org/10.1080/03066150.2021.1961130

Marijnen, E. (2017). The "Green Militarization" of development aid: The European Commission and the Virunga National Park, DR Congo. Third World Quarterly, 38(7): 1566-1582.

Marijnen, E., de Vries, L. \& Duffy, R. V. (2021). Conservation in violent environments. Political Geography 87 https://doi.org/10.1016/j.polgeo.2020.102253

Marijnen, E., \& Verweijen, J. (2016). Selling green militarization: The discursive (re)production of militarized conservation in the Virunga National Park, Democratic Republic of the Congo. Geoforum, 75: 274-285. https://doi.org/10.1016/j.geoforum.2016.08.003

Martinez-Alier, J. (2003). The Environmentalism of the poor: A study of ecological conflicts and valuation. Edward Elgar.

Massé, F. (2019). Anti-poaching's politics of (in)visibility: Representing nature and conservation amidst a poaching crisis. Geoforum, 98: 1-14. https://doi.org/10.1016/j.geoforum.2018.09.011

Massé, F. (2018). Topographies of security and the multiple spatialities of (conservation) power: Verticality, surveillance, and space-time compression in the bush. Political Geography, 67: 56-64. https://doi.org/10.1016/j.polgeo.2018.10.001

Massé, F. \& Lunstrum, E. (2016). Accumulation by securitization: Commercial poaching, neoliberal conservation, and the creation of new wildlife frontiers. Geoforum, 69: 227-237. https://doi.org/10.1016/j.geoforum.2015.03.005

Massé, F. \& Margulies, J. (2020). The geopolitical ecology of conservation: The emergence of illegal wildlife trade as national security interest and the re-shaping of US foreign conservation assistance. World Development, 132. https://doi.org/10.1016/j.worlddev.2020.104958

Massé, F., Dickinson, H., Margulies, J., Joanny, L., Lappe-Osthege, T. \& Duffy, R. V. (2020). Conservation and crime convergence? Situating the 2018 London Illegal Wildlife Trade Conference. Journal of Political Ecology, 27: 23-42. https://doi.org/10.2458/v27i1.23543

McDonald, M. (2008). Securitization and the construction of security. European Journal of International Relations, 14: 563-587. https://doi.org/10.1177\%2F1354066108097553

McDonald, M., Barnett, J., \& O'Brien, K., (eds.) (2010). Global environmental change and human security. MIT Press.

Moreto, W. \& Charlton, R. (2021). Rangers can't be with every elephant: assessing rangers' perceptions of a community, problem-solving policing model for protected areas. Oryx, 55(1): 89-98. http://doi.org/10.1017/S0030605318001461

Nyman, J. (2016). What is the value of security? Contextualising the negative/positive debate. Review of International Studies, 42(5): 821-839. https://doi.org/10.1017/S0260210516000140

Neumann, R. P. (2004). Moral and discursive geographies in the war for biodiversity in Africa. Political Geography, 23(7): 813-837. https://doi.org/10.1016/j.polgeo.2004.05.011

Oels, A. (2012). From 'securitization' of climate change to 'climatization' of the security field: comparing three theoretical perspectives. in Scheffran, J., Brzoska, M., Brauch, H. G., Link P. M. \& Schilling, J. (eds.) Climate change, human security and violent conflict (pp.185-205). Springer.

OBrien, K., \& Barnett, J. (2013). Global environmental change and human security. Annual Review of Environment and Resources, 38(1): 373-391. https://doi.org/10.1146/annurev-environ-032112-100655

O'Lear, S. (2018). Environmental Geopolitics. Rowman \& Littlefield. 
Peluso, N. L. \& Vandergeest, P. (2011). Political ecologies of war and forests: Counterinsurgencies and the making of national natures. Annals of the Association of American Geographers, 101(3): 587-608.

Peluso, N. L. \& Watts, M. J. (eds.) (2001), Violent environments. Cornell University Press.

Pyhälä, A., Osuna Orozco A. \& Counsell, S. (2016). Protected Areas in the Congo Basin: Failing both people and biodiversity? Rainforest Foundation UK.

Robbins, P. (2012). Political ecology: A critical introduction. $2^{\text {nd }}$ ed. Wiley.

Rocheleau, D. E., Thomas-Slayter, B. \& Wangari, E. (1996). Gender and environment: A feminist political ecology perspective. In Rocheleau, D. E., Thomas-Slayter, B. \& Wangari, E. (eds.), Feminist political ecology: Global issues and local experiences. (pp. 3-24). Routledge.

Selby, J., Dahi, O. S., Fröhlich, C.\& Hulme, M. (2017). Climate change and the Syrian Civil War revisited. Political Geography, 60: 232-244. https://doi.org/10.1016/j.polgeo.2017.05.007

Somerville, K. (2017). Ivory: Power and poaching in Africa. Oxford University Press.

Soulé, M. E. (1985). What is Conservation Biology? BioScience, 35 (11): 727-734. https://doi.org/10.2307/1310054

Spapens, T., White, R., Van Uhm, D. \& Huisman, W., (eds.) (2018). Green crimes and dirty money. Routledge.

Thakholi, L. (2021). Conservation labour geographies: Subsuming regional labour into private conservation spaces in South Africa. Geoforum, 123: 1-11. https://doi.org/10.1016/j.geoforum.2021.04.019

van Uhm, D. \& Moreto, W. D. (2018). Corruption within the Illegal Wildlife Trade: A symbiotic and antithetical enterprise. British Journal of Criminology, 58: 864-885. https://doi.org/10.1093/bjc/azx032

Weldemichel, T. G. (2020). Othering pastoralists, state violence, and the remaking of boundaries in Tanzania's militarised wildlife conservation sector. Antipode, 52(5): 1496-1518. https://doi.org/10.1111/anti.12638

White, A. (2019). Soldier, contractor, trauma: The governance of post-traumatic stress disorder in the private military labour market. Illness, Crisis, and Loss, 27(4): 274-292.

Witter, R. (2021). Why militarized conservation may be counter-productive: illegal wildlife hunting as defiance. Journal of Political Ecology, 28(1): 175-192. https://doi.org/10.2458/jpe.2357

Wright, E., Bhammar, H., González-Velosa, A., \& Sobrevila, C. (2016). Analysis of international funding to tackle illegal wildlife trade. World Bank Group. http://hdl.handle.net/10986/25340

Wyatt, T. (2013). Wildlife trafficking: A deconstruction of the crime, the victims and the offenders. Palgrave Macmillan.

Ybarra, M. (2012). Taming the jungle, saving the Maya Forest: Sedimented counterinsurgency practices in contemporary Guatemalan conservation. The Journal of Peasant Studies, 39(2): 479-502. 